\title{
Two extraction-free reverse transcription loop-mediated isothermal amplification assays for detection of SARS-CoV-2
}

\author{
Meng Yee Lai ', Fatma Diyana Mohd Bukhari', Nur Zulaikha Zulkefli', Ilyiana Ismail², Nur Izati Mustapa², \\ Tuan Suhaila Tuan Soh², Afifah Haji Hassan², Kalaiarasu M. Peariasamy ${ }^{3}$, Yee Leng Lee ${ }^{4}$, Jeyanthi Suppiah ${ }^{5}$, \\ Ravindran Thayan ${ }^{5}$ and Yee Ling Lau ${ }^{1 *}$
}

\begin{abstract}
Background: Current assays for detection of severe acute respiratory syndrome coronavirus 2 (SARS-CoV-2) rely on time consuming, costly and laboratory based methods for virus isolation, purification and removing inhibitors. To address this limitation, we propose a simple method for testing RNA from nasopharyngeal swab samples that bypasses the RNA purification step.
\end{abstract}

Methods: In the current project, we have described two extraction-free reverse transcription loop-mediated isothermal amplification (RT-LAMP) assays for the detection of SARS-CoV-2 by using E gene and RdRp gene as the targets.

Results: Here, results showed that reverse transcription loop-mediated isothermal amplification assays with 88.4\% sensitive (95\% Cl: 74.9-96.1\%) and 67.4\% sensitive (95\% Cl: 51.5-80.9\%) for E gene and RdRp gene, respectively.

Conclusion: Without the need of RNA purification, our developed RT-LAMP assays for direct detection of SARS-CoV-2 from nasopharyngeal swab samples could be turned into alternatives to qRT-PCR for rapid screening.

Keywords: SARS-CoV-2, Isothermal detection, Coronaviruses, Rapid diagnosis, RT-LAMP

\section{Background}

Coronavirus disease 2019 or COVID-19 is a contagious viral infection that attacks humans, primarily the throat and lungs. This disease, which is caused by severe acute respiratory syndrome coronavirus 2 (SARS-CoV-2), must infect living cells in order to reproduce. The presence of new COVID-19 variants makes the disease more infectious and rapidly emerging. In today's scenario where the world is struggling and fighting against the novel coronavirus, real-time polymerase chain reaction or RT-PCR is the most reliable test for the detection of COVID-19

\footnotetext{
*Correspondence: lauyeeling@um.edu.my

${ }^{1}$ Department of Parasitology, Faculty of Medicine, University of Malaya, 50603 Kuala Lumpur, Malaysia

Full list of author information is available at the end of the article
}

infection [1-4]. However, looking at the reality of the current situation where the pandemic is spread so broadly, there is a need to be thinking about another scale of testing which is simple-to-use, fast and cost effective. Consequently, isothermal methods such as loop-mediated isothermal amplification (LAMP) has come to the fore as a great alternative to the RT-PCR method [5-7].

Previously, laboratory screening test of SARS-CoV-2 using RT-PCR exploits a few different types of detection gene including envelope $(E)$ gene, nucleocapside $(N)$ gene $[2,8]$ and RNA dependent RNA Polymerase $(R d R p)$ gene [2]. These genes are significant for overall function of coronavirus and conserved [9]. These genes have been used in RT-LAMP as well [5, 7-11], however most of these methods required RNA extraction and purification using commercial kits which is costly and time consuming. 
In this study, we amplified $E$ gene and $R d R p$ gene using RT-LAMP assay using direct nasopharyngeal swab specimens, without RNA extraction and purification. With this optimization, detection of SARS-CoV-2 could be performed directly on clinical samples as a point-of-care test utilizing readily available reagents and equipment.

\section{Methods and results \\ Source of samples}

A total of 43 rRT-PCR positive $\left(C_{t}\right.$ values range: 14.4$38.85)$ and 15 rRT-PCR negative nasopharyngeal and oropharyngeal swabs samples were involved in these RT-LAMP assays. During rRT-PCR assay, the RNA from these samples were extracted by using QIAamp viral RNA Mini kit (Qiagen, Hilden, Germany) according to the manufacturer's instructions. These samples involved in this study were obtained from Hospital Sungai Buloh and Institute for Medical Research, Malaysia. Upon collection, each swab sample was placed into a sterile vial containing 2-mL of viral transport media (VTM) and preheated at $65{ }^{\circ} \mathrm{C}$ for $1 \mathrm{~h}$. An aliquot of $250 \mu \mathrm{L}$ of each swab samples were frozen and sent to University of Malaya on dry ice. This study was approved by UMMC Medical Ethics Committee (202041-8418) and Medical Research Ethics Committee (MREC) Ministry of Health Malaysia (NMRR-20-2344-56994).

\section{RNA extraction-free protocol}

Here, we described a column-free RNA preparation method. The RNA was extracted from swabs samples using bovine serum albumin (BSA) based method following the procedures described by Plante et al. [12] and Wozniak et al. [13] with minor modification. A total of $2.5 \mu \mathrm{L}$ swab sample in VTM was mixed with $47.5 \mu \mathrm{L}$ of $1 \mathrm{mg} / \mathrm{mL}$ BSA solution (1:20 ratio). The mixture was then vortex for $30 \mathrm{~s}$ followed by quick spin. The supernatant $(14.16 \mu \mathrm{L})$ was used as a template for RT-LAMP assay.

\section{RT-LAMP assays}

$E$ gene and $R d R p$ gene of SARS-CoV-2 were selected as our target regions in the present study. Table 1 indicates the primer sequences of both genes. The primers were specifically designed using Primer-Explorer V4 software (Eiken Chemical Co., Ltd., Tokyo, Japan) based on SARS-CoV-2 envelope protein (GenBank accession no: MT192773.1, MT192772.1, MT669322.1 and MT646120.1) and RNA-dependent RNA Polymerase (GenBank accession no: LR757995.1, LR757998.1 and MT192773.1). Each of the samples was tested separately with 2 primers sets following BSA extraction step. The assay was performed in a total reaction volume of $30 \mu \mathrm{L}$ consisting of $3 \mu \mathrm{L}$ of $10 \times$ isothermal amplification buffer II, $1.8 \mu \mathrm{L}$ of $100 \mathrm{mM} \mathrm{MgSO}{ }_{4}, 1.68 \mu \mathrm{L}$ of $100 \mathrm{mM}$ dNTPs,
Table 1 LAMP E gene and RdRp gene primers used in this study

\begin{tabular}{cl}
\hline Primer & Sequence $\left(\mathbf{5}^{\prime} \mathbf{-} \mathbf{3}^{\prime}\right)$ \\
\hline Egene & \\
FIP & CGCAGTAAGGATGGCTAGTGTAGCGTACTTCTTTTTCTTGCTT \\
BIP & TCGATTGTGGCGTACTGCTGTTTTAACACGAGAGTAAACGT \\
FLP & CTAGCAAGAATACCACG \\
BLP & GTTAACGTGAGTCTTG \\
F3 & TTTCGGAAGAGACAGGTAC \\
B3 & AGGAACTCTAGAAGAATTCAGA \\
RdRp gene & \\
FIP & TGAGCACACTCATTAGCTAATCTCGCAAACATACAACGTGTTG \\
BIP & GAGTGAAATGGTCATGTGTGGAAGCAGTTGTGGCATCTC \\
FLP & GAAACGGTTGACAAGCT \\
BLP & GTTAAACCAGGTGGAACCTC \\
F3 & TGGCCTCACTTGTTCTTG \\
B3 & AGCTTGACAAATGTTAAAACAC \\
\hline
\end{tabular}

1.2 $\mu \mathrm{L}$ of Bacillus stearothermophilus (Bst) 3.0 DNA polymerase (NEB, Ipswich, United States), $4.56 \mu \mathrm{L}$ of primer mix, $1.2 \mu \mathrm{L}$ RNaseOUT $^{\mathrm{TM}}$ recombinant ribonuclease inhibitor (Invitrogen, California, United States), $2.4 \mu \mathrm{L}$ of hydroxynaphthol blue (HNB) (Sigma, St. Louis, USA) and $14.16 \mu \mathrm{L}$ of RNA. The reaction mixture was incubated in Loopamp Real-Time Turbidimeter LA 500 (Eiken Chemical Co., Ltd., Taito-ku, Japan) at $65^{\circ} \mathrm{C}$ for $45 \mathrm{~min}$. Additional upfront of HNB in the master mix was used for direct observation of colour changes on end products. Positive LAMP reaction shows sky blue whereas negative reaction remained in violet colour. The cost per reaction of LAMP ( $\$ 1.77 \mathrm{USD} /$ reaction) is much cheaper than rRT-PCR ( \$11.94 USD/reaction).

\section{Analytical sensitivity and specificity test}

To determine the analytical sensitivity for $E$ gene and $R d R p$ gene, a recombinant plasmid carrying $E$ gene or $R d R p$ fragments of SARS-CoV-2 were constructed. F3 and B3 primers set were used to amplify the target genes from synthetic fragments (Sangon Biotec Co., Ltd., Shanghai, China). The PCR conditions were as follows: denaturation at $94{ }^{\circ} \mathrm{C}$ for $5 \mathrm{~min}, 30$ cycles of $94{ }^{\circ} \mathrm{C}$ for $30 \mathrm{~s}$, $55^{\circ} \mathrm{C}$ for $60 \mathrm{~s}$ and $72{ }^{\circ} \mathrm{C}$ for $30 \mathrm{~min}$, and a final extension step at $72{ }^{\circ} \mathrm{C}$ for $10 \mathrm{~min}$. Following the PCR amplification, the amplified products were purified prior to cloned into pGEM-T vector (Promega Corporation, Madison, USA) and transformed into TOP10F' E. coli competent cells. The recombinant plasmids were extracted using Qiagen Spin Miniprep kit (Qiagen, Hilden, Germany) and sent for sequencing to confirm its identity. The pGEM-T vector containing either $E$ gene or $R d R p$ inserts were linearized by SalI and transcribed into RNA by 
RiboMAX $^{\mathrm{TM}}$ Large Scale RNA Production Systems (Promega Corporation, Madison, United States) according to the manufacturer's instruction. The RNA copy number was calculated based on the following formula: copies $/ \mu \mathrm{L}=\left[\left(6.02 \times 10^{23} \times 10^{-9}\right) \times\right.$ concentration $\left.(\mathrm{ng} / \mu \mathrm{L})\right] /$ (fragment length $\times 340)^{4}$ ). Ten-fold serial dilutions of the transcribed RNA ranging from $1 \times 10^{6}$ copies $/ \mu \mathrm{L}$ to $1 \mathrm{copy} / \mu \mathrm{L}$ were prepared. Each of the dilution factors was tested in triplicates in RT-LAMP assay. Results showed that the limit of detection of the transcribed RNA both $E$ gene and $R d R p$ gene was 1 copy $/ \mu \mathrm{L}$.

\section{Clinical sensitivity and specificity test}

The specificity of the $E$ gene and $R d R p$ gene in RT-LAMP assay was tested using genomic RNA of coronavirus, adenovirus 4, influenza A H3N2, influenza B, novel influenza A H1N1, parainfluenza virus 1, parainfluenza virus 2 , parainfluenza virus 3 , respiratory syncytial virus (subtype A) and syncytial virus (subtype B) (Vircell, Granada, Spain). Each of the genomic RNA was tested in triplicates. Results showed that the specificity was $100 \%$.

Next, the clinical sensitivity and specificity of RTLAMP was evaluated using 58 swabs samples. The sensitivity was calculated based on the formula: (number of true positives)/(number of true positives + number of false negatives) and the specificity was calculated as (number of true negatives)/(number of true negatives + number of false positives). Out of 43 rRT-PCR positive samples and 15 rRT-PCR negative samples, RTLAMP using $E$ gene detected only 38 samples as positive and 13 samples as negative. The RT-LAMP using $E$ gene was $88.4 \%$ sensitive (95\% CI: $74.9-96.1 \%$ ) and 86.7\% specific (95\% CI: 59.5-98.3). Positive and negative predictive values for RT-LAMP targeting $E$ gene were 95.0\% (95\% CI: 83.88-98.58) and 72.2\% (95\% CI: $52.70-$ $85.85)$, respectively. In other words, $95.0 \%$ of all swabs samples tested for the detection of COVID-19 infection were actually had the SARS-CoV-2 infections and $72.2 \%$ of swabs samples were truly virus-free infection tested by RT-LAMP using $E$ gene. On the other hand, for RT-LAMP using $R d R p$ gene, 29 rRT-PCR positive samples were detected as positive and $13 \mathrm{rRT}$-PCR negative samples were detected as negative. RT-LAMP using $R d R p$ gene was $67.4 \%$ sensitive (95\% CI: $51.5-80.9 \%$ ) and 86.7\% specific (95\% CI: 59.5-98.3\%) (Additional file 1: Table S1). The positive predictive value is $93.5 \%$ (95\% CI: 79.69-98.17) and the negative predictive value is $48.1 \%$ (95\% CI: 36.64-59.86).

\section{Discussion}

To mitigate the COVID-19 outbreak, development of simple and rapid molecular based methods for direct detection of SARS-CoV-2 virus in respiratory samples is an urgent need. To bypass the RNA purification step, many alternative methods enabling simple nucleic acid extraction from SARS-CoV-2 have been described. Most of the investigators focused on RNA extraction from saliva samples instead of swab samples. Such methods involve using a commonly found reagent in molecular biology laboratories, such as bovine serum albumin (BSA), proteinase $\mathrm{K}$ and formamide. Lalli et al. managed to extract RNA from saliva samples by combination of heating steps and proteinase $\mathrm{K}$ treatment [14]. Result shows that the limit of detection (LOD) of RTLAMP was down to $10^{2}$ viral genomes. Meanwhile, Li et al. reported an extraction-free RT-LAMP method by incorporation of $6 \%$ formamide into reaction mixture. They managed to obtain 5 copies $/ \mu \mathrm{L}$ within 45 min [15]. Wei et al. reported a RT-LAMP based testing on RNAspike samples by using an in-house lysis buffer. Results showed the LOD of this method as low as 2.5 copies/ $\mu \mathrm{L}$ RNA [16]. Meanwhile, Dudley et al. developed a fluorescence-based RT-LAMP test using direct nasopharyngeal swab samples without any treatment and showed a LOD of $1 \times 10^{2}-1 \times 10^{4}$ copies/ $\mu \mathrm{L}$ [17]. Mautner et al. has described a RT-LAMP assay for the detection of SARSCoV-2 directly from pharyngeal swab samples by using $O R F B$ and $N$ gene as the target regions [18]. Their report showed a LOD of 100 copies/ $\mathrm{LL}$ RNA for both genes. In the work presented here, we developed a BSA-based extraction method for the detection of SARS-CoV-2. By adding $2.5 \mu \mathrm{L}$ of VTM into $47.5 \mu \mathrm{L}$ BSA $(1 \mathrm{mg} / \mathrm{mL})$ followed by $30 \mathrm{~s}$ vortex, the sample can be served directly as the template for RT-LAMP assay. We managed to develop two RT-LAMP assays for direct detection of SARS-CoV-2 in VTM in $45 \mathrm{~min}$. RT-LAMP results showed that sensitivity for both $E$ gene and $R d R p$ was 1 copy $/ \mu \mathrm{L}$. These RT-LAMP assays are rapid and simple if compared to conventional nucleic acid extraction kits as no purification step is required. Overall RNA extraction method took approximately 2 min to complete.

In the two extraction-free assays developed here, clinical sensitivity of RT-LAMP based on $E$ gene and $R d R p$ gene were 88.4 and $67.4 \%$, respectively. However, our results indicated a barely lower sensitivity of RTLAMP assay than other studies. Nawattanapaiboon et al. obtained $95.8 \%$ sensitivity by using $R d R p$ as target gene during their development of colorimetric RT-LAMP for SARS-CoV-2 detection [19]. Jang et al. managed to obtain 93.9\% sensitivity of the $R d R p$ gene in the development of multiplex RT-LAMP for on-site SARS-CoV-2 diagnosis [20]. Meanwhile for $E$ gene as the target region in RTLAMP assay, Yang et al. shows a $98.5 \%$ sensitivity during the development of triplex RT-LAMP assay for the detection of SARS-CoV-2 [21]. Pang et al. demonstrated a $94 \%$ sensitivity of $E$ gene during their development of 
RT-LAMP combination with clustered regularly interspaced short palindromic repeats (CRISPRs) technology in the detection of SARS-CoV-2 [22]. All these assays were conducted using commercial kits. Our developed RT-LAMP presented a lower sensitivity as compared to other findings, it may need further optimization. On top of that, RNA maybe degraded during storage or shipment. Further study basing on larger sample size could have generated more accurate results.

Apart from this, we performed several trials of using unprocessed swab samples, at which the collected swab samples were not subjected to any pre-treatment with chemicals and heat-inactivated procedures. As suggested by Ladha et al. only $10 \%$ of the amount from total reaction volume was used as a template. Several other amounts of swab samples, $1,2.5$ and $5 \mu \mathrm{L}$ were tested as well. Unfortunately, no amplification result was obtained [23]. According to Anahtar et al. direct RT-LAMP testing of unprocessed specimens from nasopharyngeal swab samples could only reliably detect samples with abundant SARS-CoV-2 $\left(3 \times 10^{6}\right.$ copies $\left./ \mathrm{mL}\right)[24]$.

\section{Conclusions}

Here we have demonstrated a simple and inexpensive BSA based extraction method for RT-LAMP assays for the detection SARS-CoV-2. This assay can be performed in any clinical laboratory, diagnostic centres and mobile laboratory with a biological safety level cabinet, as it does not require any other specialized equipment. Taken together, this assay can be employed as an alternative diagnosis method in resource limited settings and thereby alleviating supply kits and reagents issues.

\section{Abbreviations}

COVID-19: Coronavirus disease 2019; SARS-CoV-2: SARS-associated coronavirus; E gene: Envelope protein; RdRp gene: RNA-dependent RNA polymerase.

\section{Supplementary Information}

The online version contains supplementary material available at https://doi. org/10.1186/s12879-021-06876-0.

Additional file 1: Table S1. RT-LAMP and real time RT-PCR results.

\section{Acknowledgements}

We acknowledge support of $\mathrm{NIH}$ Biodefense and Emerging Infections Research Resources Repository, NIAID, NIH for providing the following reagents; gamma-irradiated SARS-coronavirus, NR-9547. We would like to thank the Director General of Health Malaysia for his permission to publish this article.

\section{Authors' contributions}

MYL, FDMB and NZZ wrote the manuscript and contributed in study design. II, NIM, TSTS, AHH, KMP, YLL, JS and RT collected the data and confirmed the patient's diagnosis. MYL and YLL analyzed the data. All authors read and approved the final manuscript.

\section{Funding}

This study was supported by Prototype Research Grant Scheme (PRGS), PR001-2020B from the Ministry of Education, Malaysia.

\section{Availability of data and materials}

The analysed data sets generated during the study are available from the corresponding author on reasonable request.

\section{Declarations}

\section{Ethics approval and consent for participation}

Informed consent forms were obtained from all study participants. Informed consent forms were obtained from all study participants. This study was approved by University Malaya Medical Centre (UMMC) Medical Ethics Committee (202041-8418) and Medical Research Ethics Committee (MREC) Ministry of Health Malaysia (NMRR-20-2344-56994). All methods and informed consent process were performed in accordance with the relevant guidelines and regulations by Medical Research and Ethics Committee Ministry of Health Malaysia.

\section{Consent for publication \\ Not applicable.}

\section{Competing interests}

The authors declare that they have no known competing financial interests or personal relationships that could have appeared to influence the work reported in this manuscript.

\section{Author details}

${ }^{1}$ Department of Parasitology, Faculty of Medicine, University of Malaya, 50603 Kuala Lumpur, Malaysia. ${ }^{2}$ Department of Pathology, Hospital Sungai Buloh, Ministry of Health, Kuala Lumpur, Malaysia. Institute for Clinical Research, National Institutes of Health, Ministry of Health, Kuala Lumpur, Malaysia. ${ }^{4}$ Clinical Research Centre, Hospital Sungai Buloh, Ministry of Health, Kuala Lumpur, Malaysia. ${ }^{5}$ Virology Unit, Infectious Disease Research Centre, Institute for Medical Research, National Institutes of Health, Ministry of Health, Kuala Lumpur, Malaysia.

Received: 21 June 2021 Accepted: 10 November 2021

Published online: 17 November 2021

\section{References}

1. Centers for Disease Control and Prevention, CDC (2020). Evaluating and testing persons for coronavirus disease 2019 (COVID-19). vol. 2019.

2. Corman VM, Landt O, Kaiser M, Molenkamp R, Meijer A, Chu DK, et al. Detection of 2019 novel coronavirus (2019-nCoV) by real-time RT-PCR. Euro Surveill. 2020;25(3):1-8.

3. Ministry of Health Malaysia. Guidelines COVID-19 Management in Malaysia No. 5/2020. 2020. Available at: https://extranet.who.int/goarn/guide lines-covid-19-management-malaysia.

4. World Health Organization. Laboratory testing strategy recommendations for COVID-19. 2020. Available at: https://apps.who.int/iris/handle/ 10665/331509.

5. Huang WE, Lim B, Hsu CC, Xiong D, Wu W, Yu Y, et al. RT-LAMP for rapid diagnosis of coronavirus SARS-CoV-2. Microb Biotechnol. 2020;13(4):95061. https://doi.org/10.1111/1751-7915.13586.

6. Lau YL, Ismail I, Mustapa NI, Lai MY, Tuan Soh TS, Hassan A, et al. Real-time reverse transcription loop-mediated isothermal amplification for rapid detection of SARS-CoV-2. Peer J. 2020;6:1-9. https://doi.org/10.7717/ peerj.9278.

7. Zhang Y, Odiwuor N, Xiong J, Sun L, Nyaruaba RO, Wei H, et al. Rapid molecular detection of SARS-CoV-2 (COVID-19) virus RNA using colorimetric LAMP. MedRxiv. 2020;164:1453. https://doi.org/10.1101/2020.02. 26.20028373

8. Lu R, Zhao X, Li J, Niu P, Yang B, Wu H, et al. Genomic characterisation and epidemiology of 2019 novel coronavirus: implications for virus origins and receptor binding. Lancet. 2020;1:19-21. 
9. Wu A, Peng Y, Huang B, Ding X, Wang X, Niu P, et al. Commentary Genome Composition and divergence of the novel Coronavirus (2019nCoV) originating in China. Cell Host Microbe. 2020;27(3):325-8.

10. Rodel J, Egerer R, Suleyman A, Sommer-schmid B, Baier M, Henke A, et al. Use of the variplex ${ }^{\text {TM }}$ SARS-CoV-2 RT-LAMP as a rapid molecular assay to complement RT-PCR for COVID-19 diagnosis. J Clin Virol. 2020;132(1):104616

11. Thompson D, Lei Y. Mini review: recent progress in RT-LAMP enabled COVID-19 detection. Sens Actuators Reports. 2020;2(1): 100017. https:// doi.org/10.1016/j.snr.2020.100017.

12. Plante $D$, Bélanger $G$, Leblanc $D$, Ward $P$, Houde A, Trottier $Y L$. The use of bovine serum albumin to improve the RT-qPCR detection of foodborne viruses rinsed from vegetable surfaces. Lett Appl Microbiol. 2010;52:239-44

13. Wozniak A, Ariel C, Ibarra-Henríquez C, Sebastian V, Armijo G, Lamig L, et al. A simple RNA preparation method for SARS-CoV-2 detection by RT-qPCR. Sci Rep. 2020;10:16608.

14. Lalli MA, Chen X, Langmade SJ, Fronick CC, Sawyer CS, Burcea LC, et al. Rapid and extraction-free detection of SARS-CoV-2 from saliva with colorimetric LAMP. Sci Rep. 2020. https://doi.org/10.1101/2020.05.07.20093 542.

15. Li J, Hu X, Wang X, Yang J, Zhang L, Deng Q, et al. A novel one-pot rapid diagnostic technology for COVID-19. Anal Chim Acta. 2021;154: 338310. https://doi.org/10.1016/j.aca.2021.338310

16. Wei S, Koh E, Djandji A, Morgan S, Whittier S, Mansukhani M, et al. Direct diagnostic testing of SARS-CoV-2 without the need for prior RNA extraction. Sci Rep. 2021;11:2402. https://doi.org/10.1038/s41598-021-81487-y.

17. Dudley DM, Newman CM, Weiler AM, Ramuta MD, Shortreed CG, Heffron AS, et al. Optimizing direct RT-LAMP to detect transmissible SARS-CoV-2 from primary nasopharyngeal swab and saliva patient samples. PLoS ONE. 2020. https://doi.org/10.1371/journal.pone.0244882.

18. Mautner L, Baillie C, Herold HM, Volkwein W, Guertler P, Eberle U, et al. Rapid point-of-care detection of SARS-CoV-2 using reverse transcription loop-mediated isothermal amplifcation (RT-LAMP). Virol J. 2020;17:160. https://doi.org/10.1186/s12985-020-01435-6.

19. Nawattanapaiboon $K$, Pasomsub E, Prombun $P$, Wongbunmak $A$, Jenjitwanich A, Mahasupachai $P$, et al. Colorimetric reverse transcription loop-mediated isothermal amplification (RT-LAMP) as a visual diagnostic platform for the detection of the emerging coronavirus SARS-CoV-2. Analyst. 2021:146:471-7. https://doi.org/10.1039/D0AN01775B.

20. Jang WS, Lim DH, Yoon J, Kim A, Lim M, Nam J, et al. Development of a multiplex loop-mediated isothermal amplification (LAMP) assay for onsite diagnosis of SARS CoV-2. PLoS ONE. 2021;16(3): e0248042. https://doi. org/10.1371/journal.pone.0248042.

21. Yang W, Dang X, Wang Q, Xu M, Zhao Q, Zhou Y, et al. Rapid detection of SARS-CoV-2 using reverse transcription RT-LAMP method. medRxiv Preprint. 2020. https://doi.org/10.1101/2020.03.02.20030130.

22. Pang $B, X u J$, Liu Y, Peng $H$, Feng W, Cao Y, et al. Isothermal amplification and ambient visualization in a single tube for the detection of SARSCoV-2 using loop-mediated amplification and CRISPR technology. Anal Chem. 2020;92:16204-12. https://doi.org/10.1021/acs.analchem.0c04047.

23. Ladha A, Joung J, Abudayyeh OO, Gootenberg JS, Zhang F. A 5-min RNA preparation method for COVID-19 detection with RT-qPCR. medRxiv Preprint. 2020. https://doi.org/10.1101/2020.05.07.20055947.

24. Anahtar MN, McGrath GEG, Rabe BA, Tanner NA, White BA, Lennerz JKM, et al. Clinical assessment and validation of a rapid and sensitive SARSCoV-2 test using reverse transcription loop-mediated isothermal amplification without the need for RNA extraction. OFID. 2020;8:2. https://doi. org/10.1093/ofid/ofaa631.

\section{Publisher's Note}

Springer Nature remains neutral with regard to jurisdictional claims in published maps and institutional affiliations.
Ready to submit your research? Choose BMC and benefit from:

- fast, convenient online submission

- thorough peer review by experienced researchers in your field

- rapid publication on acceptance

- support for research data, including large and complex data types

- gold Open Access which fosters wider collaboration and increased citations

- maximum visibility for your research: over $100 \mathrm{M}$ website views per year

At BMC, research is always in progress.

Learn more biomedcentral.com/submissions 